This item was submitted to Loughborough's Research Repository by the author.

Items in Figshare are protected by copyright, with all rights reserved, unless otherwise indicated.

\title{
Training through work experience
}

PLEASE CITE THE PUBLISHED VERSION

PUBLISHER

(C) WEDC, Loughborough University

VERSION

VoR (Version of Record)

PUBLISHER STATEMENT

This work is made available according to the conditions of the Creative Commons Attribution-NonCommercialNoDerivatives 4.0 International (CC BY-NC-ND 4.0) licence. Full details of this licence are available at: https://creativecommons.org/licenses/by-nc-nd/4.0/

\section{LICENCE}

CC BY-NC-ND 4.0

\section{REPOSITORY RECORD}

Tayler, W.K.. 2019. "Training Through Work Experience”. figshare. https://hdl.handle.net/2134/29880. 
9th 1979 Conference: Sanitation and water for development in Africa: HARARE: 1983

TRAINING THROUGH WORK EXPERIENCE

by $W K$ TAYLER

\section{INTRODUCTION}

The goals of the water Decade are very ambitious and considerable commitment and careful planning will be required if they are to be even approached. It is important to identify the factors which inhibit development and to allow for these factors in Decade programmes. Two common inhibiting factors are lack of finance or material resources and the shortage of trained personnel. These factors present a serious obstacle to the development of water services in urban areas in southern sudan. The present paper argues that attempts to tackle the problems posed by the lack of material resources and the shortage of trained personnel separately have been unsuccessful. It describes the Author's experience in working with a small team of sudanese engineers on works to improve urban water supplies, points out the drawbacks encountered because of lack of resources and suggests an approach to aid which will result in improved water supply facilities and at the same time provide Sudanese staff with valuable work experience. A proposed development programme is outline, which will give work experience to water engineers and maintenance technicians. It will also make correct operation of water supply systems possible and hence prepare the way for on-the-job training programmes for operational staff.

\section{THE BACKGROUND SITUATION}

It is necessary to give some background information on Southern sudan and its urban water supplies in order to put the jdeas and arguments presented in the paper into perspective. Sudan is the largest country in Africa and the Southern Region, with an area of approximately 650,000 square kilometres, includes about a quarter of the land area and has a population of about 4 million. The population is predominantly rural but Juba, Wau and Malakal, with approximate populations of $120,000,80,000$ and 60,000 respectively, are sizeable towns. Several other towns have populations in the range 10,000 to 20,000. Juba, the seat of the Regional Government, is over $1200 \mathrm{~km}$ from Khartoum and communications are difficult, both within the Region and with the rest of the country.

Like other African countries, Sudan has been adversely affected by the recession in the world economy and it is currently faced with severe financial problems. At the same time, there is a shortage of trained manpower, particularly in the Southern Region where development was seriously set back by the civil war that ended in 1972. In view of these facts, it is inevitable that the Region relies heavily on the assistance of aid organisations and this is certainly true in the case of urban water supplies.

\section{Urban water supply facilities}

The water supply systems at Juba, Wau and Malakal are based on river abstraction with rapid gravity sand filtration and were originally designed to serve populations of around 10,000. Although there have been additions to the original systems, facilities have failed to expand to match the growth of the towns so that large areas in each are without piped water. The systems are in a poor state of repair, due partly to the difficulties in obtaining parts and materials and partly to the lack of well trained maintenance staff. Some, but not all, of the smaller towns have piped water supplies. In areas without piped water supplies, a variety of water sources is used, ranging from boreholes to rivers and streams. Water carriers operate extensively in Juba and Malakal and the price of water from these carriers is up to fifteen times the official rate for piped water.

Consultants have prepared reports on water supplies to Wau and Malakal which will lead to large reconstruction schemes if finance can be arranged. The reports recommend measures to be taken to improve water supplies to the towns in the interim period. A feasibility study is also planned for Juba where GTZ, the German technical aid agency are carrying out a programme of interim measures. GTz have also been involved with water supply schemes for Yambio and Maridi, two of the smaller towns. 


\section{Organisation of urban water supplies}

Until recently, urban water supplies were the responsibility of the public Electricity and water Corporation (PEWC), a public corporation based in Khartoum. The southern area of PEWC was based in Juba and covered the whole of the Southern Region. Water and electricity services are in the process of being decentralised but the new arrangements have not yet been finalised. The Regional Ministry of Housing and Public Utilities (RMH\&PU) has been involved with the schemes for water supply improvements, particularly those funded by GTZ. The Southern Area has an operational deficit which has been met partly by PEWC, Khartoum and partly by the Regional Government. A priority of any development programme must be to take measures to reduce this deficit.

\section{EXISTING FORMS OF ASSITANCE}

Assistance to Sudan in the fields of urban water supply and sanitation has until now taken two forms. The first is the provision of finance for consultants to carry out feasibility studies, intended to lead to the detailed design and then construction of new facilities. A consultant's report can provide a useful statement of the overall strategy to be followed but the procedure has drawbacks for a poorly developed area like Southern sudan. It tends to concentrate development into discrete periods of intense work at widely spaced intervals, precluding the substantial involvement of local institutions and ensuring heavy dependency on expatriate personnel. Thus, the procedure does nothing to build up local expertise and increase a country's self-reliance. The concentration on construction also tends to push the need for correct operation and maintenance procedures and training into the background. Two effects of this approach are that local engineers and technicians are underworked, quickly becoming demoralised and losing interest, and that the inflexibility of the procedure leads to delays in execution while problems remain unsolved and water services deteriorate.

The second form of assistance, scholarships for academic study abroad, has little relevance in a situation such as that described above. All technical disciplines require a combination of practical experience and theoretical knowledge and the knowledge gained through study is rapidly lost if not put into use. Lasting development can only occur if steps are taken to fully involve local personnel in schemes to improve water and sanitation facilities. Aid programmes must operate as far as is possible through local institutions which must be strengthened and supported where necessary to enable them to function effectively.

\section{THE SOUTHERN SUDAN PROGRAMME}

The programme which is the subject of this paper is an attempt to apply the principles suggested in the previous paragraph. The first stage has been to set up a small team of engineers within the RMH\&PU to work on the planning, design and construction of water supply projects. Support and guidance is provided by an experienced engineer reccuited by VSO, the British volunteer organisation, and employed by the RMFiPU. The Author, the first such engineer, started work in March 1981 and is due to be replaced in early 1983. There will be an overlap period of at least two months to ensure continuity. Both the Author and his replacement have been recruited from British water authorities.

Plans are in hand to extend the programme to include the training of mechanical and electrical maintenance technicians. VSO or the organisation Water Aid, based in the British water industry and intended as a response to the water Decade, will be used to recruit experienced technicians to assist in this part of the programme. The first priority will be to improve and repair existing facilities. This will enable correct operational procedures to be introduced so that the training programme can be extended to include operational staff. As the reliability of water services is increased, their profitability will improve and it should be possibje to reduce the operating deficit. Some attention will also have to be given to the training of accounting and administrative staff. Once the present position has been consolidated, it will be possible to start to expand services. The various elements in the programme are described in more detail below.

\section{New works team}

The team is directly responsible to the Director of the RMH\&PU and consjsts at present of the Author, two graduate civil engineers and a draughtsman. All the Sudanese members of the team have previous engineering experience but none directly related to water. One of the engineers attended a watex resources course in Britain in the first half of 1982 and it is hoped to send the second engineer to Loughborough for the MSC course in 1983. The aim of the team is to give engineers and technicians a grounding in the principles and practice of water supply work and, at the same time, improve the state of water supplies in the 
Southern Region. Training is given as far as is possible through the work of the team but inevitably there are gaps in the knowledge gained in this way and directed reading and design examples are used to fill these gaps. A task which has been carried out by one member of the team may be repeated by another if it illustrates important principles. The intention is to cover a range of subjects including the planning of overall water supply strategy, hydraulic design of waterworks units and water mains, the layout of waterworks and distribution systems, a knowledge of the available plant and materials, prepaxation of working drawings, drawing office procedures and construction techniques.

To date (October 1982) most of the work of the team has concerned Juba. The immediate needs are largely covered by the GTz interim measures programme, for which a German firm of consulting engineers is responsible for supervision and procurement of materials. The work in hand also includes the installation of three pre-fabricated steel sedimentation tanks. The team has taken over responsibility for this work and it is also planned to involve team members in the GTZ programme.

The disadvantage of working alongside an already established programme is that work cannot be followed through from beginning to end. The important decisions as to which work is required, how it should be executed and which materials are required have already been made. A more comprehensive approach is possible for Wau and Malakal. Programmes of essential work are being prepared by the team, based on the consultant's immediate measures proposals but including other items, identified after examining the water supply system in each town.

A good example of a measure to improve the functioning of a system without incurring a large expenditure occurs at Malakal. The town is flat and extends about $5 \mathrm{~km}$ along and an average of $1 \mathrm{~km}$ back from the River Nile. At present, the distribution system is fed by gravity from a 15 metres high tank at the waterworks. The main features of the original distribution system were $4 "$ and 6" mains running paralled to the river. An 8" main, laid in the early 1970s also runs the length of the town but the number of connections to it are not in proportion to its size. Water pressures throughout the town are extremely low. Approximate calculations indicate that they can be improved by dividing the distribution system into two zones, that nearer the waterworks served by gravity from the high-level tank while new pumps with a delivery head of around 40 metres supply the further zone directly via the 8" main. Some new connections will be required, both at the waterworks and in the distribution system. This improvement provides a useful exercise, requiring estimates of demand, approximate hydraulic design, pump selection and some detailed design. If implemented successfully it will also provide greater income since improved pressures will bring an increased demand for house connections and public water points.

\section{Operations and maintenance}

At present, water operations in southern Sudan are affected by a serious shortage of maintenance technicians and well trained staff for the day to day supervision of water treatment and distribution operations. If the proposed programme is to be effective, it is essential that it includes provision for the training of operations and maintenance staff. As a first step, agreement has been reached with the British Council to provide funds to enable up to six students to attend technicians courses. The Kenya Polytechnic runs sandwich courses for water, electrical and mechanical technicians and it is hoped that sudanese students will be accepted for these courses. The required practical work experience will be given partly through the improvement programme and trainees will also spend some time working in a programme to improve and standardise operational procedures. Some specialist assistance will be required and discussions have been held with water Aid on the possibility of providing both short term and longer term assistance.

Operator training As a first step, water Aid is recruiting for an experienced waterworks superintendent to visit the southern Region to advise on operational and maintenance procedures. Part of his task will be to put forward ideas on an overall training programme for operations staff which will be implemented when some steps have been taken to facilitate the correct operation of existing systems. The training programme will include a sizeable element of training at the workplace. Part of the practical work experience of the water engineering technicians will be to assist in this training and to implement and record improved operational practices.

Electrical installation The electrical arrangements at the Juba, wau and Malakal waterworks are inadequate and there is considerable scope for improvement and standardisation. In each case, a complete re-wiring is probably advisable. The 
proposed improvement programmes will include provision for this work which will be carried out by sudanese trainees in conjunction with an experienced electrical technician recruited through VSO or water Aid.

Mechanical maintenance Mechanical work requiring attention includes the repair of pumps, filtex control mechanisms and bulk meters and the maintenance of tools and vehicles. Routine and maintenance schedules must be established. As with the electrical installation work, it is planned that this work will be carried out by sudanese trainees working alongside experienced expatriate volunteers.

\section{PROBLEMS AND POSSIBLE SOLUTIONS}

The most obvious problem in Southern Sudan is the difficulty experienced in obtaining matexials for even the most basic improvement schemes. Apart fron the physical fact of distance when ordering and transporting materials, there is the problem of lack of finance which is particularly acute because many materials require foreign exchange for their purchase. Manufacturer's catalogues and other technical information axe being gathered in the Juba design office to assist in ordering equipment and materials but there remains the problems of financing and transporting purchases, particularly those which must be imported. One attractive possibility is that of providing imported materials through commodity aid, the materials required being specified by the new works engineexs or maintenance personnel in accordance with their own plans and estimates. Several aid donors have been approached about the possibility of making a small amount available each year to assist the proposed work programme. An initial. materials and equipment expenditure of perhaps E100,000 per annum is envisaged, increasing as the capability of the implementing personnel increases to a ceiling which might be set at about $\$ 250,000$ per annum. Locally available materials and labour would be supplied by the Regional Government so that the rate of progress would very much depend on Sudanese commitment. The first work to be implemented if some assistance is forthcoming will be the immedjate measures at Wau and Malakal.

The problems caused by inadequate finance will undoubtedly continue to occur in many countries through the water Decade and beyond. Repayment of interest on large loans may be difficult and hence there will be a reluctance to implement large scale projects. Changes should be made in the terms of reference for feasibility studies so that consultants are asked to produce proposals which can be implemented over a period as a series of small contracts combined, where appropxiate, with the use of direct labour. This will ensure development, albeit at a slow rate. If arrangements are made for the supply of imported materials such as pipes and fittings, much of the work can be carried out by local contractors, thus adding to the knowledge and experience available for continued development. Unless there is this emphasis on starting in a small way and involving local institutions and manpower, the water Decade will fall far short of its aims in urban areas in many countries in Africa. 